\title{
SIFAT FISIKO-KIMIA DAN MUTU ORGANOLEPTIK BAKSO BROILER DENGAN MENGGUNAKAN TEPUNG UBI JALAR (Ipomoea batatas L)
}

\author{
Siska Montolalu *), N. Lontaan ${ }^{* *}$ ), S. Sakul ${ }^{* *}$ ), A. Dp. Mirah ${ }^{* *}$ ) \\ Fakultas Peternakan Universitas Sam Ratulangi Manado, 95115. \\ email: sisca.montolalu@yahoo.com
}

\begin{abstract}
ABSTRAK
Penelitian ini bertujuan untuk mengetahui efek berbagai prosentase tepung ubi jalar terhadap sifat fisiko-kimia dan mutu organoleptik bakso broiler. Variabel yang diamati adalah sifat fisik dan Sifat Organoleptik bakso. Data untuk semua peubah dianalisis menurut prosedur analisis ragam (ANOVA) dari Rancangan Acak Lengkap dan untuk mengetahui perlakuan mana yang berbeda nyata secara statistik dilakukan pengujian dengan Uji Wilayah Berganda Duncan. Untuk uji organoleptik digunakan metode Scoring Deffrent test dengan jumlah panelis 35 orang. Hasil penelitian ini menunjukan bahwa penambahan presentase tepung ubi jalar hingga 20\% berpengaruh sangat nyata $(\mathrm{P}<0.01)$ terhadap Daya Mengikat Air dan Kadar Air. Tapi tidak berpengaruh nyata $(\mathrm{P}>0.05)$ terhadap $\mathrm{pH}$. Hasil Organoleptik menunjukkan bahwa perlakuan memberikan pengaruh yang sangat nyata $(\mathrm{P}<0.01)$ terhadap tekstur, kekenyalan, dan citarasa. Tapi tidak berpengaruh nyata $(\mathrm{P}>0.05)$ terhadap aroma. Berdasarkan hasil penelitian dan analisa data dapat disimpulkan bahwa penambahan tepung ubi jalar sebagai filler hingga prosentase $20 \%$ menghasilkan bakso broiler dengan sifat fisiko-kimia yang baik dan secara organoleptik dapat diterima oleh konsumen.
\end{abstract}

Kata Kunci: Bakso broiler, Tepung ubi jalar, Sifat fisiko-kimia dan Mutu organoleptik.

\section{ABSTRACT}

\footnotetext{
* Alumni Fakultas Peternakan

** Jurusan Produksi Ternak
}

PHYSICO-CHEMICAL PROPERTIES AND SENSORY QUALITY OF BROILER MEATBALLS USING SWEET POTATO FLOUR (Ipomoea batatas $L$ ). The experiment was conducted to determine the effect of various percentages of sweet potato flour on physico-chemical properties and sensory quality of broiler meatballs. Variables observed were, physical and organoleptical properties of meat ball. Data for all variables were analyzed according to the procedure of analysis variance (ANOVA) of the completely randomized design, and to determine which treatments were significantly different statistically tested by Duncan Multiple Test Region. For organoleptic tests used the "Scoring Deffrent test" with panelists number 35 people. These results indicate that the addition of sweet potato flour percentage to $20 \%$ was highly significant $(\mathrm{P}<0.01)$ on Water and Power Binds Moisture. But no significant effect (P> 0.05) on $\mathrm{pH}$. Organoleptic results showed that the treatment gives a highly significant effect $(\mathrm{P}<0.01)$ the texture, firmness, and flavor. But no significant effect $(\mathrm{P}>0.05)$ on aroma. Based on the research and analysis of the data it can be concluded that the addition of sweet potato flour as a filler to produce a percentage of $20 \%$ of broiler meatballs with physico-chemical properties and organoleptic well accepted by consumers.

Keywords: Broiler meatballs, Sweet potato flour, Physico-chemical properties and Organoleptic quality. 


\section{PENDAHULUAN}

Daging merupakan salah satu komoditas peternakan yang dibutuhkan untuk memenuhi kebutuhan protein hewani karena mengandung protein bermutu tinggi dan mampu memenuhi zat gizi yang dibutuhkan oleh tubuh. Daging dapat diolah dalam berbagai jenis produk yang menarik dengan aneka bentuk dan rasa untuk tujuan memperpanjang masa simpan serta dapat meningkatkan nilai ekonomis tanpa mengurangi nilai gizi dari daging yang diolah. Olahan daging yang sudah lama dikenal dan sangat digemari masyarakat Indonesia adalah bakso. Bakso merupakan produk olahan daging dimana daging tersebut telah dihaluskan terlebih dahulu dan dicampur dengan bumbu, tepung, dan kemudian dibentuk seperti bola-bola kecil lalu direbus dalam air panas. Pendistribusian bakso di wilayah Indonesia sudah sangat luas sehingga produk ini memegang peranan penting dalam penyebarluasan protein hewani bagi konsumsi zat gizi masyarakat Indonesia. Ditinjau dari aspek gizi, bakso merupakan makanan yang mempunyai kandungan protein hewani, mineral dan vitamin yang tinggi.

Bakso yang ada di pasaran umumnya merupakan bakso yang berasal dari daging sapi, walaupun demikian tidak menutup kemungkinan bakso dapat dibuat dari daging ternak lainnya seperti broiler. Broiler banyak digunakan dalam pembuatan bakso karena broiler mempunyai kelebihan antara lain termasuk daging putih, lebih disukai, harganya relatif murah, kandungan kolesterol yang rendah, lebih empuk, lembut, halus, tulang dada lentur, marbling yang cukup dan jaringan lemak yang minimal. Bakso dibuat dari campuran daging tidak kurang dari $50 \%$ dan pati atau tepung serealia, dengan atau tanpa bahan tambahan makanan yang diizinkan. Bakso biasanya disajikan bersama mi atau bihun, sayuran, dan kuah. Bakso diperkenalkan ke Indonesia oleh perantau dari Cina.

Proses pembuatan bakso pada umumnya menggunakan tepung tapioka. Adapun penambahan tepung sebagai filler bakso berguna untuk memperbaiki tekstur, meningkatkan daya ikat air, menurunkan penyusutan akibat pemasakan dan meningkatkan elastisitas produk. Dalam rangka penganekaragaman pangan, fungsi ini bisa digantikan dengan tepung lain seperti tepung ubi jalar. Tepung ubi jalar memiliki kelebihan yaitu sebagai sumber karbohidrat, serat pangan, betakaroten dan memiliki kandungan gula yang cukup tinggi sehingga dalam pembuatan produk olahan berbahan tepung ubi jalar dapat mengurangi penggunaan gula sebanyak 20\%. Tepung ubi jalar mengandung 60-70\% amilopektin dan $17.8 \%$ amilosa. Ubi jalar yang berwarna putih lebih diarahkan untuk pengembangan tepung dan pati karena umbi yang berwarna cerah cenderung lebih baik kadar patinya dan warna tepung lebih menyerupai terigu.

\section{MATERI DAN METODE PENELITIAN}

Penelitian ini dilaksanakan di Laboratorium Teknologi Hasil Ternak Fakultas Peternakan Universitas Sam Ratulangi Manado pada tanggal 2- 16 Agustus 2012. Bahan baku utama dalam penelitian ini adalah broiler 
bagian dada sebanyak 1600 gram dan bahan pengisinya adalah tepung ubi jalar sebanyak 200 gram serta bahanbahan lain untuk masing-masing perlakuan yaitu STPP, es/ air es, garam, lada, bawang putih dan msg. Alat-alat yang digunakan untuk pembuatan bakso adalah penggiling daging, timbangan electrik, sendok, wadah-wadah plastik, pisau, dan telenan. Peralatan yang digunakan untuk melakukan analisa sifat fisiko kimia bakso adalah pH-meter, timbangan elektrik, blender, gelas ukur, kertas saring Whatman 42, barbel, oven dan penjepit kaca. Peralatan yang digunakan untuk uji organoleptik bakso adalah piring, garpu, gelas, kertas tisu, pisau, kertas kuisioner dan alat tulis. Rancangan percobaan yang digunakan dalam penelitian ini adalah Rancangan Acak Lengkap (RAL) dengan 4 Perlakuan dan ulangan sebanyak 5 kali (Steel dan Torrie, 1993) serta uji organoleptik yang digunakan adalah Scoring Defference Tests (Soekarto, 1985). Perlakuan yang diterapkan adalah: $\mathrm{T} 1=$ Bakso dengan $5 \%$ tepung ubi jalar, $\mathrm{T} 2=$ Bakso dengan $10 \%$ tepung ubi jalar, T3 = Bakso dengan $15 \%$ tepung ubi jalar dan T4= Bakso dengan 20\% tepung ubi jalar.

Pembuatan ubi jalar diakukan dengan cara ubi jalar berwarna putih sebanyak $1,5 \mathrm{~kg}$ dicuci bersih dari tanah dan kotoran, kemudian dikupas pada air mengalir. Pengirisan dilakukan dengan menggunakan pisau dan dipotong tipis-tipis setebal $0,5 \mathrm{~cm}$ kemudian dicuci kembali dan ditiriskan dihamparkan pada bak oven. Pengeringan pada oven dilakukan pada suhu $50-60^{\circ} \mathrm{C}$ selama 2 hari. Setelah itu irisan ubi yang telah kering digiling dengan menggunakan blender dan diayak sampai memperoleh tepung. Pembuatan bakso dilakukan dengan cara daging ayam yang diambil pada bagian dada seberat 1600 gram dibersihkan terlebih dahulu, kemudian dipotong-potong menjadi ukuran yang lebih kecil dan dipisahkan menjadi 4 bagian dengan berat masing-masing 400 gram untuk setiap perlakuan. Lalu masing-masing perlakuan dicampur dengan bahanbahan seperti $1,5 \%$ garam, $20 \%$ es batu, tepung ubi jalar sesuai perlakuan, $0,25 \%$ lada, $0,5 \%$ bawang putih, $0,25 \% \mathrm{msg}$ dan $0.25 \%$ STPP kemudian dimasukkan ke dalam alat penggilingan (food processor) dan digiling. Prosentase penambahan bahan tambahan dihitung dari berat daging. Adonan kemudian dibentuk menjadi bulat-bulat dengan cara mengambil segenggam adonan, kemudian remas dan tekan kearah ibu jari. Adonan yang keluar dari antara ibu jari dan telunjuk akan membentuk bulatan, kemudian bakso tersebut dimasukkan ke dalam air panas bersuhu $80^{\circ} \mathrm{C}$ hingga mengapung. Bakso diangkat dan ditiriskan.

Variabel yang diamati dam diukur dalam penelitian ini adalah : Sifat Fisiko-Kimia yaitu pH, kadar air dan daya mengikat air. Uji Organoleptik yaitu aroma, tekstur, kekenyalan dan citarasa. Data untuk semua peubah dianalisis menurut prosedur analisis ragam (ANOVA) dari Rancangan Acak Lengkap dan untuk mengetahui perlakuan mana yang berbeda nyata secara statistik dilakukan pengujian dengan Uji Wilayah Berganda Duncan. 


\section{HASIL DAN PEMBAHASAN}

\section{Pengaruh Perlakuan terhadap Sifat Fisiko-Kimia Bakso Broiler}

Hasil pengukuran dan perhitungan dari masing-masing perlakuan terhadap nilai rataan untuk sifat fisiko-kimia bakso broiler dalam penelitian ini dapat dilihat pada Tabel 1.

\section{Nilai pH}

Nilai $\mathrm{pH}$ adalah sebuah indikator penting kualitas daging dengan memperhatikan kualitas teknologi dan pengaruh kualitas daging segar. Pengamatan terhadap $\mathrm{pH}$ penting dilakukan karena perubahan $\mathrm{pH}$ berpengaruh terhadap kualitas bakso yang dihasilkan (Soeparno 1998 dalam Sudrajat 2007). Dari hasil pengukuran pH bakso yang tercantum pada Tabel 1 , menunjukkan bahwa nilai rataan $\mathrm{pH}$ bakso broiler dengan prosentase tepung yang berbeda berkisar antara 6.40 sampai 6.48 dengan nilai rataan tertinggi pada prosentase tepung $20 \%$ $\left(\mathrm{T}_{4}\right)$ yaitu 6.48 dan terendah terdapat pada prosentase tepung $5 \%\left(\mathrm{~T}_{1}\right)$ yaitu 6.40. Nilai $\mathrm{pH}$ pangan menurut Standarisasi Nasional Indonesia yaitu berkisar antara 6 sampai 7 hal ini berarti bahwa nilai $\mathrm{pH}$ dalam penelitian ini masih memenuhi batasan $\mathrm{pH}$ menurut Standarisasi Nasional Indonesia.

Berdasarkan analisis sidik ragam penambahan prosentase tepung ubi jalar pada bakso ayam broiler tidak memberikan pengaruh yang nyata $(\mathrm{P}>$ 0.05) terhadap nilai $\mathrm{pH}$ broiler. Dari hasil penelitian ini terlihat kecenderungan nilai $\mathrm{pH}$ meningkat. Hal ini dipengaruhi oleh bahan dasar yang digunakan yaitu daging dan tepung. Nilai $\mathrm{pH}$ bahan dasar ini mengakibatkan perubahan nilai $\mathrm{pH}$ pada bakso. Hal ini terjadi akibat adanya perubahan keseimbangan hidrogen pada bakso sebagai pengaruh dari nilai $\mathrm{pH}$ bahan dasar yang digunakan dalam pembuatan bakso. Pencampuran bahan-bahan membuat titik keseimbangan hidrogen yang baru pada bakso. Sesuai pendapat Pearson dan Dutson (1994), bahwa perubahan susunan struktur pada daging restrukturisasi dalam fungsinya sebagai protein daging telah terbukti mempengaruhi $\mathrm{pH}$ produk yang dihasilkan.

\section{Kadar Air (\%)}

Air merupakan komponen penting dalam bahan makanan karena air dapat mempengaruhi penampakan, tekstur, serta citarasa makanan. Selain itu sebagian besar dari perubahanperubahan makanan terjadi dalam media air yang ditambahkan atau berasal dari bahan itu sendiri (Winarno, 1997).

Pengukuran kadar air bakso yang tercantum pada Tabel 5, menunjukkan bahwa nilai rataan kadar air dalam penelitian ini berkisar antara $57.34 \%$ sampai $64.72 \%$ dengan rataan terendah pada prosentase tepung $20 \%(57.34 \%)$ dan rataan tertinggi pada prosentase tepung 5\% $(64.72 \%)$. Kadar air bakso menurut SNI 01-3818-1995 yaitu maksimal $70.0 \%$, hal ini berarti bahwa kadar air bakso dalam penelitian ini masih memenuhi batasan kadar air menurut Standarisasi Nasional Indonesia. Penelitian Maharaja (2008), melaporkan bakso dengan campuran tepung tapioka dan tepung sagu mengandung kadar air antara $60.69 \%$ sampai $71.25 \%$. Dari hasil analisis sidik ragam menunjukan bahwa 
perlakuan memberikan pengaruh yang sangat nyata $(\mathrm{P}<0.01)$ terhadap kadar air $(\%)$ bakso ayam broiler. Hal ini berarti bahwa penambahan tepung ubi jalar sebagai filler memberikan perbedaan pada kadar air bakso broiler.

Analisis lebih lanjut menggunakan uji wilayah berganda Duncan menunjukan bahwa perlakuan $\mathrm{T}_{1}$ ( prosentase tepung 5\%) berbeda sangat nyata terhadap perlakuan $\mathrm{T}_{2}$ (prosentase tepung 10\%), perlakuan $\mathrm{T}_{3}$ (prosentase tepung 15\%) dan perlakuan $\mathrm{T}_{4}$ (prosentase tepung 20\%). Perlakuan $\mathrm{T}_{2}$ berbeda sangat nyata terhadap perlakuan $T_{1}$ dan perlakuan $\mathrm{T}_{4}$, tapi berbeda tidak nyata terhadap perlakuan $T_{3}$. Perlakuan $T_{3}$ berbeda sangat nyata terhadap perlakuan $\mathrm{T}_{1}$ dan perlakuan $\mathrm{T}_{4}$ tapi berbeda tidak nyata terhadap perlakuan $\mathrm{T}_{2}$. Perlakuan $\mathrm{T}_{4}$ berbeda sangat nyata terhadap perlakuan $T_{1}$, perlakuan $T_{2}$ dan perlakuan $\mathrm{T}_{3}$.

Penelitian ini menunjukkan bahwa semakin tinggi prosentase tepung ubi jalar maka kadar air bakso broiler semakin menurun. Penurunan kadar ini disebabkan karena tepung berfungsi sebagai bahan pengikat yang dapat meningkatkan daya mengikat air, dimana tepung akan mengikat air yang berada dalam matriks daging sehingga kadar air bakso semakin menurun. Hal ini sesuai dengan pernyataan Manullang et al. (1995) yang menyatakan penurunan kadar air akibat mekanisme interaksi pati dan protein sehingga air tidak dapat diikat secara sempurna karena ikatan hidrogen yang seharusnya mengikat air telah dipakai untuk interaksi pati dan protein. Dengan demikian semakin tinggi prosentase tepung yang digunakan maka massa tepung didalam bakso akan semakin besar dan kadar air bakso akan semakin menurun. Penurunan ini juga disebabkan karena pati yang terkandung dalam tepung menambah berat total dan bersifat menyerap air, sedangkan kandungan air didalam daging tetap. Akibatnya kandungan air menurun (Maharaja, 2008).

\section{Daya Mengikat Air (\%)}

Daya mengikat air oleh protein adalah kemampuan daging untuk mengikat Airnya atau air yang ditambahkan selama ada pengaruh kekuatan dari luar misalnya pemotongan daging, pemanasan, penggilingan dan tekanan (Soeparno, 2005). Daya mengikat air merupakan hal yang penting untuk kualitas daging dan produk daging termasuk bakso (Natasasmita et al., 1987). Semakin besar daya mengikat air, semakin tinggi presentasi air yang terikat dalam produk .

Dari hasil pengukuran daya mengikat air bakso yang tercantum pada Tabel 1, menunjukkan bahwa nilai rataan daya mengikat air dalam penelitian ini berkisar antara $34.35 \%$ sampai $48.82 \%$ dengan rataan terendah pada prosentase tepung 5\% $(34.35 \%)$ dan rataan tertinggi pada prosentase tepung 20\% (48.82\%). Berdasarkan hasil analisis sidik ragam menunjukan bahwa perlakuan memberikan pengaruh yang berbeda sangat nyata ( $\mathrm{P}>0.01)$ terhadap daya mengikat air bakso broiler.

$$
\text { Analisis lebih lanjut }
$$
menggunakan uji wilayah berganda Duncan menunjukan bahwa perlakuan $\mathrm{T}_{1}$ (prosentase tepung 5\%) berbeda nyata terhadap perlakuan $\mathrm{T}_{3}$ (prosentase tepung 15\%) dan 
perlakuan $\mathrm{T}_{4}$ (prosentase tepung 20\%) tapi tidak berbeda nyata terhadap perlakuan $\mathrm{T}_{2}$ (prosentase tepung 10\%). Perlakuan $\mathrm{T}_{2}$ berbeda nyata terhadap perlakuan $\mathrm{T}_{1}$ dan perlakuan $\mathrm{T}_{4}$ tapi tidak berbeda nyata terhadap $\mathrm{T}_{3}$. Perlakuan $T_{3}$ berbeda nyata terhadap perlakuan $\mathrm{T}_{1}$ dan tidak berbeda nyata terhadap perlakuan $\mathrm{T}_{2}$ dan perlakuan $\mathrm{T}_{4}$. Perlakuan $\mathrm{T}_{4}$ berbeda nyata terhadap perlakuan $\mathrm{T}_{1}$ dan perlakuan $\mathrm{T}_{2}$ dan tidak berbeda nyata terhadap perlakuan $\mathrm{T}_{3}$.

Penelitian ini menunjukan bahwa semakin tinggi prosentase penambahan tepung ubi jalar maka kemampuan bakso untuk mengikat air semakin tinggi. Tepung berpati dapat meningkatkan daya mengikat air karena mempunyai kemampuan menahan air selama proses pengolahan dan pemanasan (Ockerman, 1983). Apabila pati dipanaskan, maka granula pati akan bervibrasi secara cepat sampai akhirnya ikatan antara molekuler pecah dan sisi hidrogennya akan mampu mengikat air dalam jumlah yang lebih banyak (Whistler dan Daniel, 1985).

Tabel 1. Nilai Rataan Sifat Fisiko-Kimia Bakso Broiler Pada Setiap Prosentase Tepung Ubi Jalar

\begin{tabular}{cccc}
\hline \multirow{2}{*}{ Tepung Ubi Jalar } & \multicolumn{3}{c}{ Variabel Fisiko-Kimia } \\
\cline { 2 - 4 } & $\mathbf{p H}$ & Kadar Air (\%) & $\begin{array}{c}\text { Daya Mengikat Air } \\
(\%)\end{array}$ \\
\hline $5 \%$ & $6.40^{\mathrm{a}}$ & $64.72^{\mathrm{a}}$ & $34.35^{\mathrm{a}}$ \\
$10 \%$ & $6.42^{\mathrm{a}}$ & $61.07^{\mathrm{b}}$ & $40.11^{\mathrm{a}}$ \\
$15 \%$ & $6.44^{\mathrm{a}}$ & $60.59^{\mathrm{b}}$ & $47.09^{\mathrm{b}}$ \\
$20 \%$ & $6.48^{\mathrm{a}}$ & $57.34^{\mathrm{c}}$ & $48.82^{\mathrm{b}}$ \\
\hline
\end{tabular}

Keterangan : Superskrip yang berbeda pada kolom yang sama menunjukkan berbeda nyata

\section{Pengaruh Perlakuan terhadap Mutu Organoleptik Bakso Broiler}

Hasil pengukuran dan perhitungan dari masing-masing perlakuan terhadap mutu organoleptik bakso broiler dalam penelitian ini dapat dilihat pada Tabel 2.

\section{Aroma}

Menurut Soekarto ( 1985) aroma disebut juga pencicipan jarak jauh karena manusia dapat mengenal enaknya makanan yang belum terlihat hanya dengan mencium aromanya dari jarak jauh, manusia dapat mencium bau yang keluar dari makanan karena adanya sel-sel epitel alfaktori di bagian dinding atas rongga hidung yang peka terhadap komponen bau. Aroma bakso dipengaruhi oleh aroma daging, aroma tepung bahan pengisi, bumbu-bumbu dan bahan lain yang ditambahkan. Pemasakan dapat mempengaruhi warna, bau, rasa dan produk daging (Sudrajat, 2007) .

Pengujian organoleptik yang tercantum pada Tabel 2, menunjukkan bahwa tingkat kesukaan panelis terhadap aroma bakso broiler pada prosentase tepung yang berbeda berada pada kisaraan rataan skor terendah 4.63 (agak suka) pada prosentase tepung 20\% sampai rataan skor tertinggi 5.37 (suka) pada level tepung 5\%. Hasil penelitian menunjukkan bahwa semakin tinggi prosentase penambahan tepung maka 
semakin rendah tingkat kesukaan panelis. Hal ini diduga karena panelis lebih menyukai aroma bakso yang berbau daging dibanding dengan aroma tepung. Selama pemasakan akan terjadi berbagai reaksi antara bahan pengisi dan daging, sehingga aroma daging berkurang selama pengolahan produk (Sudrajat, 2007). Berdasarkan hasil analisis sidik ragam menunjukkan bahwa perlakuan tidak memberikan pengaruh yang nyata ( $\mathrm{P}$ $<0.05$ ) terhadap aroma bakso ayam.

\section{Tekstur}

Tekstur bakso ditentukan oleh kandungan air, kandungan lemak dan jenis karbohidrat. Kandungan air yang tinggi akan menghasikan tekstur yang lembek begitu juga dengan kadar lemak yang tinggi akan menghasilkan bakso yang berlubang-lubang sehingga dapat mempengaruhi tektur bakso (Octavianie, 2002). Aspek yang dinilai dari tekstur bakso ditandai dengan kasar atau halusnya produk yang dihasilkan (Soeparno, 2005)

Pengujian organoleptik yang tercantum pada Tabel 2, menunjukkan bahwa nilai rataan tingkat kesukaan panelis terhadap tekstur bakso broiler berkisar antara 4.51 ( agak halus) sampai 5.94 (Halus). Rataan skor tertinggi berada pada prosentase tepung $20 \%$ dan rataan skor terendah pada prosentase tepung $5 \%$.

Berdasarkan hasil analisis keragaman menunjukan bahwa perlakuan memberikan pengaruh yang sangat nyata $(\mathrm{P}<0.01) \quad$ terhadap tekstur bakso ayam broiler. Dengan uji wilayah berganda Duncan menunjukkan bahwa perlakuan $\mathrm{T}_{1}$ (prosentase tepung 5\%) berbeda sangat nyata terhadap perlakuan $\mathrm{T}_{4}$ (prosentase tepung 20\%) tapi tidak berbeda nyata terhadap perlakuan $\mathrm{T}_{2}$ (prosentase tepung 10\%) dan perlakuan $\mathrm{T}_{3}$ (prosentase tepung $15 \%$ ). Perlakuan $\mathrm{T}_{2}$ berbeda sangat nyata terhadap perlakuan $T_{4}$ tapi tidak berbeda nyata terhadap perlakuan $T_{1}$ dan perlakuan $T_{3}$. Perlakuan $T_{3}$ berbeda sangat nyata terhadap perlakuan $\mathrm{T}_{4}$ tapi tidak berbeda nyata terhadap perlakuan $T_{1}$ dan perlakuan $\mathrm{T}_{2}$. Perlakuan $\mathrm{T}_{4}$ berbeda nyata terhadap perlakuan $T_{1}$, perlakuan $T_{2}$, dan perlakuan $\mathrm{T}_{3}$.

Daging ayam mempunyai tekstur yang halus karena daging ayam mempunyai serabut otot yang kecil, sehingga mempunyai struktur miofibril yang lebih kecil. Menurut Lawrie (2003), salah satu hal yang mempengaruhi tekstur daging adalah kandungan jaringan ikat serta ukuran berkas otot. Disamping itu kandungan protein daging ayam juga relatif tinggi, yang mempunyai kemampuan mengemulsi lemak yang lebih besar, sehingga sangat mempengaruhi tekstur bakso. Menurut Triatmojo (1992), bahwa adonan yang emulsinya stabil akan menyebabkan tekstur yang lebih baik. Tekstur juga dipengaruhi oleh tepung sebagai bahan pengisi, dimana pada saat dimasak protein daging yang mengalami pengerutan akan diisi oleh molekul-molekul pati yang dapat mengkompakkan tekstur. Kandungan gluten dari jenis tepung dapat mempengaruhi tekstur bakso. Semakin tinggi kadar gluten tepung yang digunakan maka semakin baik tekstur bakso yang dihasilkan (Maharaja, 2008). Tekstur ini juga dipengaruhi oleh garam yang digunakan, karena sifat basis dari garam menyebabkan gel sehingga viskositas karbohidrat meningkat dengan adanya pemasakan 
dan akan menghasilkan produk yang lebih kompak.

\section{Kekenyalan}

Kekenyalan merupakan bagian pembentuk tekstur yang diperhitungkan konsumen dalam menilai kesukaan dan penerimaan daging serta produknya. Kekenyalan adalah kemampuan produk pangan untuk kembali kebentuk asal sebelum produk pecah. Bakso yang kenyal akan terasa elastik jika dikunyah .

Tabel 2 menunjukan nilai rataan kekenyalan bakso broiler dengan menggunakan tepung ubi jalar. Nilai rataan kekenyalan tertinggi terdapat pada perlakuan penambahan tepung ubi jalar $20 \%$ (T4) yaitu sebesar 5.97 dan terendah terdapat pada perlakuan penambahan tepung ubi jalar $5 \%$ (T1) yaitu sebesar 4.17. Dari Tabel 2 dapat dilihat rataan uji organoleptik berkisar antara 4.17 sampai 5.97. Artinya panelis cenderung menilai kenyal.

Berdasarkan hasil analisis sidik ragam menunjukan bahwa perlakuan memberikan pengaruh yang sangat nyata ( $\mathrm{P}<0.01$ ) terhadap kekenyalan bakso broiler. Dengan uji wilayah berganda Duncan menunjukan perlakuan $T_{1}$ berbeda sangat nyata terhadap perlakuan $T_{3}$ dan perlakuan $\mathrm{T}_{4}$ tapi tidak berbeda nyata terhadap perlakuan $T_{2}$. Perlakuan $T_{2}$ berbeda sangat nyata terhadap perlakuan $\mathrm{T}_{4}$ tapi tidak berbeda nyata terhadap perlakuan $T_{1}$ dan perlakuan $T_{3}$. Perlakuan $T_{3}$ berbeda sangat nyata terhadap perlakuan $T_{1}$ dan perlakuan $\mathrm{T}_{4}$, tapi tidak berbeda nyata terhadap perlakuan $\mathrm{T}_{2}$. Perlakuan $\mathrm{T}_{4}$ berbeda sangat nyata terhadap perlakuan $T_{1}$, perlakuan $\mathrm{T}_{2}$ dan perlakuan $\mathrm{T}_{3}$.

Hasil penelitian menunjukkan bahwa semakin tinggi prosentase penambahan tepung ubi jalar maka bakso yang dihasilkan semakin kenyal. Sudarwati (2007) menyatakan bahwa nilai organoleptik meningkat seiring dengan meningkatnya campuran tepung yang ditambahkan pada bakso. Hal ini disebabkan karena dengan pencampuran tepung yang lebih banyak atau proporsi tepung yang dicampurkan pada bakso sesuai maka bakso yang dihasilkan semakin kenyal. Nilai kekenyalan ini juga dipengaruhi oleh tepung ubi jalar yang digunakan sebagai bahan pengisi (filler), karena kandungan amilopektin dapat membentuk gel yang liat apabila dipanaskan (Naruki dan Kanoni, 1992). Kandungan amilopektin dalam tepung yang tinggi dapat membentuk prosuk yang lekat. Konsumen pun lebih menyukai bakso yang kenyal dan tidak cepat pecah (Nurhayati, 2009).

\section{Citarasa}

Rasa merupakan faktor penentu daya terima konsumen terhadap produk pangan. Dalam menilai rasa lebih banyak menggunakan alat indra perasa. Pengindraan rasa dibagi menjadi 4 faktor yaitu asin, asam, manis dan pahit (Winarno, 1997). Rasa bakso dibentuk oleh berbagai rangsangan bahkan terkadang juga di pengaruhi oleh aroma dan warna . Namun pada umumnya ada 3 macam rasa bakso yang sangat menentukan penerimaan konsumen yaitu kegurihan, keasinan, dan rasa daging (Andayani, 1999 ).

Nilai citarasa pada penelitian ini (Tabel 2) dapat dilihat bahwa rataan tertinggi terdapat pada perlakuan prosentase penambahan tepung ubi jalar 5\% (T1) yaitu sebesar 5.60 dan terendah terdapat pada perlakuan prosentase penambahan tepung ubi 
jalar 20\% (T4) yaitu sebesar 4.54 . Nilai rataan hasil uji organoleptik dari keempat level tepung berkisar antara 4,54- 5,60 ( Tabel 6 ). Dalam uji skor ini telah ditentukan bahwa semakin tinggi nilai skornya semakin disukai bakso yang dihasilkan. Kisaran tersebut berada pada kondisi agak suka sampai suka. Jadi urutan tingkat citarasa dari keempat perlakuan hasil penelitian ini adalah rasa suka $\left(\mathrm{T}_{1}\right.$ dan $\left.\mathrm{T}_{2}\right)$, agak suka $\left(\mathrm{T}_{3}\right.$ dan $\left.\mathrm{T}_{4}\right)$.

Berdasarkan hasil analisis keragaman menunjukan bahwa perlakuan memberikan pengaruh yang sangat nyata $(\mathrm{P}<0.01)$ terhadap citarasa bakso daging ayam. Dengan Uji wilayah berganda Duncan menunjukkan bahwa perlakuan $\mathrm{T}_{1}$ (prosentase tepung 5\%) berbeda sangat nyata terhadap perlakuan $\mathrm{T}_{3}$ (prosentase tepung 15\%) dan perlakuan $\mathrm{T}_{4}$ (prosentase tepung 20\%) tapi tidak berbeda nyata terhadap perlakuan $\mathrm{T}_{2}$ (prosentase tepung $10 \%$ ). Perlakuan $\mathrm{T}_{2}$ berbeda nyata terhadap $\mathrm{T}_{1}$ dan tidak berbeda nyata terhadap perlakuan $T_{3}$ dan perlakuan $T_{4}$. Perlakuan $T_{3}$ berbeda nyata terhadap perlakuan $\mathrm{T}_{1}$ dan tidak berbeda nyata terhadap perlakuan $T_{2}$ dan perlakuan
$\mathrm{T}_{4}$. Perlakuan $\mathrm{T}_{4}$ berbeda nyata terhadap perlakuan $T_{1}$ dan perlakuan $\mathrm{T}_{2}$ tapi tidak berbeda nyata terhadap perlakuan $\mathrm{T}_{3}$.

Hasil penelitian menunjukkan bahwa semakin tinggi penambahan prosentase tepung maka semakin menurun tingkat kesukaan panelis terhadap bakso broiler. Menurut Nurhayati (2009), pengujian kesukaan terhadap rasa bakso bergantung pada kesukaan panelis terhadap daging yang dipakai. Pada penelitian ini umumnya panelis lebih menyukai rasa bakso yang masih terasa dagingnya. Hal ini sejalan dengan pendapat Andayani (1999) yang menyatakan sebagian besar responden menyukai bakso dengan rasa daging yang kuat. Penggunaan tepung sebagai bahan pengisi juga dapat mempengaruhi rasa, sebab amilosa dalam tepung dapat membentuk inklusi dengan senyawa cita rasa seperti garam dan bumbu-bumbu (Goldshall \& Solms, 1992). Rasa bakso juga dipengaruhi oleh garam yang ditambahkan pada saat pengolahan. Hal ini diduga karena konsentrasi garam yang ditambahkan tidak terlalu tinggi, sehingga menimbulkan rasa enak pada bakso.

Tabel 2. Rataan Mutu Organoleptik Bakso Daging Sapi pada Level Tepung Talas yang Berbeda

\begin{tabular}{cccccc}
\hline \multirow{2}{*}{ Variabel } & \multicolumn{5}{c}{ Perlakuan Level Tepung } \\
\cline { 2 - 6 } & $\mathrm{T}_{1}(5 \%)$ & $\mathrm{T}_{2}(10 \%)$ & $\mathrm{T}_{3}(15 \%)$ & $\mathrm{T}_{4}(20 \%)$ & $\mathrm{T}_{5}(25 \%)$ \\
\hline Warna & $4,55^{\mathrm{a}}$ & $5,13^{\mathrm{b}}$ & $5,26^{\mathrm{b}}$ & $5,32^{\mathrm{b}}$ & $5,32^{\mathrm{b}}$ \\
Tekstur & $3,34^{\mathrm{a}}$ & $3,97^{\mathrm{b}}$ & $5,32^{\mathrm{c}}$ & $5,47^{\mathrm{c}}$ & $5,55^{\mathrm{c}}$ \\
Kekenyalan & $3,95^{\mathrm{a}}$ & $4,26^{\mathrm{a}}$ & $5,13^{\mathrm{b}}$ & $5,34^{\mathrm{b}}$ & $5,66^{\mathrm{b}}$ \\
Citarasa & $4,84^{\mathrm{a}}$ & $4,87^{\mathrm{a}}$ & $5,47^{\mathrm{b}}$ & $5,50^{\mathrm{b}}$ & $5,53^{\mathrm{b}}$ \\
\hline
\end{tabular}

Keterangan : Superskrip berbeda pada baris yang sama berarti berbeda nyata 
Hasil analisis ragam untuk uji organoleptik menunjukkan bahwa perlakuan memberi pengaruh berbeda sangat nyata $(\mathrm{P}<0,01)$ terhadap tekstur dengan rataan skor berkisar antara 3,34 sampai 5,55 (Tabel 2). Panelis memberi kesan halus dengan nilai rataan tertinggi pada level tepung $25 \%$ dan rataan terendah pada level tepung dengan kesan tekstur agak kasar. Uji wilayah berganda Duncan menunjukkan bahwa perlakuan $\mathrm{T}_{1}$ (level tepung 5\%) berbeda sangat nyata terhadap perlakuan $\mathrm{T}_{2}$ (level tepung $10 \%$ ), $\mathrm{T}_{3}$ (level tepung $15 \%$ ), $\mathrm{T}_{4}$ (level tepung 20\%) dan $\mathrm{T}_{5}$ (level tepung 25\%). Perlakuan $\mathrm{T}_{2}$ berbeda sangat nyata terhadap perlakuan $T_{3}, T_{4}$ dan $T_{5}$. Perlakuan $T_{3}$ berbeda tidak nyata terhadap perlakuan $T_{4}$ dan $T_{5}$. Selanjutnya perlakuan $T_{4}$ berbeda tidak nyata terhadap perlakuan $T_{5}$. Penambahan tepung talas belitung hingga level $15 \%$ memberikan pengaruh sangat nyata terhadap tekstur bakso daging sapi. Daya mengikat air oleh protein daging juga mempengaruhi tekstur bakso, dimana daging dengan daya mengikat air tinggi akan menghasilkan tekstur bakso yang baik. Sejalan dengan pendapat Sunarlim (1992) bahwa penggunaan daging tanpa lemak dalam jumlah yang banyak menghasilkan tekstur bakso yang lebih kasar. Penggunaan tepung talas belitung sebagai bahan pengisi berfungsi untuk memperbaiki tekstur bakso. Hal ini dikarenakan ukuran granula pati tepung talas belitung yang besar menyebabkan pada saat proses gelatinisasi granula pati lebih cepat pecah dan hasilnya merata sehingga mempengaruhi tekstur bakso. Meningkatnya daya serap air yang lebih besar akan menyebabkan daya ikat antara partikel serpihan daging semakin kuat. Hal ini mengakibatkan bakso dengan level tepung yang lebih banyak dapat menghasilkan tekstur yang halus.

Hasil analisis ragam untuk uji organoleptik menunjukkan bahwa perlakuan memberi pengaruh berbeda sangat nyata $(\mathrm{P}<0,01)$ terhadap kekenyalan dengan rataan skor 3,955,66 (Tabel 2). Rataan tertinggi pada level tepung $25 \%$ dengan kesan kenyal dan rataan terendah berada pada level tepung 5\% dengan kesan biasa atau netral oleh panelis. Uji wilayah berganda Duncan menunjukkan bahwa perlakuan $\mathrm{T}_{1}$ (level tepung $5 \%$ ) berbeda tidak nyata terhadap perlakuan $\mathrm{T}_{2}$ (level tepung $10 \%$ ) tetapi berbeda sangat nyata terhadap perlakuan $\mathrm{T}_{3}$ (level tepung $15 \%$ ), $\mathrm{T}_{4}$ (level tepung 20\%) dan $\mathrm{T}_{5}$ (level tepung 25\%). Perlakuan $\mathrm{T}_{2}$ berbeda sangat nyata terhadap perlakuan $\mathrm{T}_{3}, \mathrm{~T}_{4}$ dan $T_{5}$. Perlakuan $T_{3}$ berbeda tidak nyata terhadap perlakuan $T_{4}$ dan $T_{5}$. Selanjutnya, perlakuan $T_{4}$ berbeda tidak nyata terhadap perlakuan $T_{5}$. Penambahan tepung talas belitung hingga pada level 20\% memberikan pengaruh sangat nyata terhadap kekenyalan bakso daging sapi. Kekenyalan berhubungan dengan kemampuan molekul pati untuk membentuk gel. Penggunaan tepung yang rendah membatasi kemampuan pati untuk membentuk gel, sehingga kekenyalan menjadi rendah (Afrianty, 2002). Amilopektin dalam pati tepung berperan dalam pembentukan gel. Karena itu, pati dengan amilopektin yang tinggi dapat membentuk produk yang lekat (Nurhayati, 2009). Selain itu, menurut Hartati dan Prana (2003) 
amilopektin juga berpengaruh terhadap swelling properties (sifat mengembang pada pati). Sifat ini dikombinasikan dengan daya mengikat air protein daging yang menyebabkan bakso mempunyai kekuatan untuk menahan tekanan dari luar dan kembali ke bentuk semula (Andayani, 1999).

Hasil analisis ragam untuk uji organoleptik menunjukkan bahwa perlakuan memberi pengaruh berbeda sangat nyata $(\mathrm{P}<0,01)$ terhadap citarasa bakso daging sapi dengan rataan skor 4,84-5,53. Uji organoleptik menunjukkan panelis memberi kesan suka untuk citarasa bakso dengan rataan tertinggi pada level tepung $25 \%$ dan rataan terendah pada level tepung 5\% dengan kesan agak suka. Uji wilayah berganda Duncan pada taraf $1 \%$ menyatakan bahwa perlakuan $\mathrm{T}_{1}$ (level tepung 5\%) berbeda tidak nyata terhadap perlakuan $\mathrm{T}_{2}$ (level tepung $10 \%$ ) tetapi berbeda sangat nyata terhadap perlakuan $\mathrm{T}_{3}$ (level tepung $15 \%$ ), $\mathrm{T}_{4}$ (level tepung 20\%) dan $\mathrm{T}_{5}$ (level tepung 25\%). Perlakuan $\mathrm{T}_{2}$ berbeda sangat nyata terhadap perlakuan $T_{3}, T_{4}$ dan $T_{5}$. Perlakuan $T_{3}$ berbeda tidak nyata terhadap perlakuan $\mathrm{T}_{4}$ dan $\mathrm{T}_{5}$. Selanjutnya perlakuan $\mathrm{T}_{4}$ berbeda tidak nyata terhadap perlakuan $\mathrm{T}_{5}$. Penambahan tepung talas belitung hingga level $20 \%$ memberikan pengaruh sangat nyata terhadap citarasa bakso daging sapi. Menurut Nurhayati (2009), pengujian kesukaan terhadap rasa bakso bergantung pada kesukaan penelis terhadap daging yang dipakai. Pemberian tepung hingga 10\% dinyatakan agak suka oleh panelis, kemungkinan disebabkan oleh karena rasa khas dari daging yang menonjol tidak begitu diminati panelis. Hal ini sedikit bertolak belakang dengan hasil studi kasus bakso Andayani (1999) di wilayah Daerah Khusus Ibukota Jakarta yang menyatakan sebagian besar responden menyukai bakso dengan rasa daging yang kuat. Selanjutnya untuk penambahan level tepung hingga $25 \%$ dinyatakan disukai oleh panelis. Penambahan tepung dapat memperbaiki citarasa bakso daging sapi jika dihubungkan dengan ukuran granula pati dan daya menyerap air yang besar sehingga selain menyerap air, tepung juga dapat menyerap bumbu yang ditambahkan untuk meningkatkan citarasa bakso. Sebagaimana dinyatakan Tranggono dkk. (1990), bahwa jumlah air yang diserap oleh pati yang semakin besar dapat menahan cairan daging dan komponen-komponen citarasa di dalamnya untuk tidak keluar selama proses pemasakan. Dengan demikian dapat dinyatakan bahwa tepung talas belitung dapat memperbaiki citarasa bakso daging sapi meski tetap memiliki batasan dalam penggunaannya. Hal ini juga di perkuat berdasarkan Standar Nasional Indonesia 01-3818-1995 yang menyatakan bahwa penggunaan bahan pengisi maksimal adalah $50 \%$ dari berat daging.

\section{KESIMPULAN}

Penambahan tepung ubi jalar sebagai filler hingga prosentase $20 \%$ menghasilkan bakso broiler dengan sifat fisiko-kimia yang baik dan secara organoleptik dapat diterima oleh konsumen. 


\section{SARAN}

Perlu dilakukan penelitian lebih lanjut untuk mengetahui komponen kimiawi ubi jalar yang berinteraksi dengan broiler dalam mempengaruhi sifat fisiko kimia dan organoleptik bakso.

\section{DAFTAR PUSTAKA}

Aberle, E. D, J. C. Forrest, D. E. Gerrard and E.W. mills. 2001. Principles of Meat Science. Fourth Ed. Kendal/Hunt Publishing Company,America.

Andayani, R.Y. 1999. Standarisasi mutu bakso berdasarkan kesukaam konsumen (studi kasus bakso di Wilayah DKI Jakarta). Skripsi. Fakultas Teknologi Pertanian. Institut Pertanian Bogor. Bogor

AOAC.1995.Official Methode Of Analysis. Association Of Official AnalyticaL Chemist, Washington DC.

Lawrie, R.A. 2003. Ilmu Daging. Edisi Kelima. Penerjemah Aminuddin Parakkasi dan Yudha Amwila. Penerbit Universitas Indonesia (UI-Press), Jakarta.

Maharaja, L. 2008. Penggunaan campuran tepung tapioka dengan tepung sagu dan natrium nitrat dalam pembuatan bakso daging sapi. Fakultas Pertanian. Universitas Sumatera Utara.

Natasasmita,S,R.Priyanto dan D.M. Tauchid. 1987. Evaluasi Daging. Fakultas Peternakan. Institut Pertanian Bogor, Bogor.

Naruki,S dan Kanoni ( 1992 ). Kimia dan Teknologi Pengolahan Hasil Hewani. Pusat Antar Universitas
(PAU) Pangan dan Gizi Universitas Gajah Mada. Yogyakarta

Ockerman.H.W, 1983. Chemistry Of Meat Tissue. Animal Science Depatemen Ohio, United State Of America.

Octavianie, Y. 2002. Kandungan gizi dan palatabilitas bakso campuran daging dan jantung sapi. Fakultas Peternakan: Institut Pertanian Bogor .

Soekarto, S.T. 1985. Penilaian Organoleptik Pusat Pengembangan Teknologi Pangan. Institut Pertanian Bogor, Press Bogor.

Soeparno. 2005. Ilmu dan Teknologi Daging .Gajah Mada Uiversity Press, Yogyakarta

Steel, R.G.D dan J.H.Torrie, 1993 . Prinsip dan Prosedur Statistika. Diterjemahkan oleh Bambang S. PT Gramedia ustaka Utama. Jakarta.

Sudarwati. 2007. Pembuatan bakso daging sapi dengan penambahan kitosan. Departemen Teknologi Pertanian Fakultas Pertanian. Universitas Sumatera Utara

Sudrajat, G. 2007. Sifat fisik dan organoleptik bakso daging sapi dan daging kerbau dengan penambahan karagenan dan khitosan. Fakultas Peternakan : Institut Pertanian Bogor

Sunarlim, R. 1992. Karakteristik mutu bakso daging sapi dan pengaruh penambahan natrium klorida dan natrium tripolifosfat terhadap perbaikan mutu. Disertasi. 
Program Pasca Sarjana, Institut Pertanian Bogor. Bogor

Triatmojo, S. 1992. Pengaruh pengantian daging sapi dengan daging kerbau, ayam dan kelinci pada komposisi dan kualitas bakso. Laporan Penelitian Fakultas Peternakan, Universitas Gadjah Mada, Yogyakarta

Winarno . F.G. 1997. Kimia Pangan dan Gizi. PT Gramedia Pustakan Utama, Jakarta. 